\title{
Disordered eating, body dissatisfaction, perfectionism, and mood state in female adolescents
}

\author{
Comportamento de risco para transtorno alimentar, \\ insatisfação corporal, perfeccionismo e estado de \\ humor em adolescentes do sexo feminino
}

Leonardo de Sousa FORTES ${ }^{1}$

Juliana Fernandes Filgueiras MEIRELES²

Clara Mockdece NEVES²

Sebastião Sousa ALMEIDA ${ }^{3}$

Maria Elisa Caputo FERREIRA²

\section{A B S T R A C T}

\section{Objective}

The aim of this study was to investigate the relationship between body dissatisfaction, perfectionism, mood, and disordered eating in female adolescents.

\section{Methods}

Three hundred and seventy one adolescents aged between 12 and 16 years of age participated in this research. The Body Shape Questionnaire, Multidimensional Perfectionism Scale, Brunel Mood Scale, and the Eating Attitudes Test - 26 were used to assess, respectively, body dissatisfaction, perfectionism, mood state, and disordered eating. Stepwise multiple linear regression was used to determine the relationship between the independent variables and the Eating Attitudes Test subscale scores. Multivariate analysis of covariance was used to compare the Eating Attitudes Test subscale scores according to body dissatisfaction, perfectionism, and mood state classifications.

\section{Results}

The findings showed that body dissatisfaction ( $p=0.001)$, perfectionism $(p=0.04)$, and mood state $(p=0.05)$ were associated with disordered eating in the female adolescents evaluated. Despite the statistically significant

\footnotetext{
1 Universidade Federal de Pernambuco, Centro Acadêmico de Vitória, Núcleo de Educação Física e Ciências do Esporte. R. Alto Reservatório, Bela Vista, 55608-680, Vitória de Santo Antão, PE, Brasil. Correspondência para/Correspondence to: LS FORTES. E-mail: <leodesousafortes@hotmail.com>; <leodesousafortes@gmail.com>.

2 Universidade Federal de Juiz de Fora, Faculdade de Educação Física e Desportos, Departamento de Fundamentos de Educação Física. Juiz de Fora, MG, Brasil.

${ }^{3}$ Universidade de São Paulo, Faculdade de Filosofia, Ciências e Letras, Departamento de Psicologia. Ribeirão Preto, SP, Brasil.
} 
results obtained for all independent variables, it is worth mentioning that body dissatisfaction was the main determinant of disordered eating in the multiple regression model.

\section{Conclusion}

It can be concluded that body dissatisfaction explains the variance in disordered eating; however, it is also important to note that perfectionism and mood state are also associated to the disordered eating in female adolescents, although to a lesser extent.

Keywords: Adolescents. Body image. Eating disorders.

\section{R E S U M O}

\section{Objetivo}

O objetivo do estudo foi verificar a relação da insatisfação corporal, do perfeccionismo e do estado de humor com o comportamento de risco para transtorno alimentar em jovens do sexo feminino.

\section{Métodos}

Participaram 371 adolescentes com idade entre 12 e 16 anos, e foram utilizados o Body Shape Questionnaire, a Multidimensional Perfectionism Scale, a Escala de Humor de Brunel e o Eating Attitudes Test - 26 para avaliar, respectivamente, insatisfação corporal, perfeccionismo, estado de humor e comportamento de risco para transtorno alimentar. Conduziu-se a regressão linear múltipla stepwise para averiguar a relação das variáveis independentes com os escores das subescalas do Eating Attitudes Test. A análise multivariada de covariância foi utilizada para comparar os escores das subescalas do Eating Attitudes Test em razão das classificações de insatisfação corporal, perfeccionismo e estado de humor.

\section{Resultados}

Os achados demonstraram que a insatisfação corporal $(p=0,001)$, o perfeccionismo $(p=0,04)$ e o estado de humor $(p=0,05)$ estiveram relacionados ao comportamento de risco para transtorno alimentar de adolescentes do sexo feminino. Embora se tenha evidenciado resultados estatisticamente significativos para todas as variáveis independentes, ressalta-se que a insatisfação corporal foi o determinante principal do comportamento de risco para transtorno alimentar no modelo de regressão múltipla.

\section{Conclusão}

Concluiu-se que a insatisfação corporal explica a variância do comportamento de risco para transtorno alimentar, no entanto vale ressaltar que o perfeccionismo e o estado de humor também se relacionam ao comportamento de risco para transtorno alimentar em adolescentes do sexo feminino, embora em menor proporção.

Palavras-chave: Adolescentes. Imagem corporal. Transtornos alimentares.

\section{INTRODUCTION}

Eating disorders (anorexia and bulimia) are psychiatric conditions with multifactorial etiology, particularly those related to socio-cultural, psychological, and behavioral factors, especially disordered eating ${ }^{1}$. Disordered eating, in turn, is related to harmful health effects ${ }^{1,2}$. Some examples of disordered eating are: restriction and binge eating, self-induced vomiting, and use of medication to control body weight (laxatives and diuretics) $)^{2}$.

The tripartite model reveals various personal and sociocultural characteristics that are directly and indirectly related to disordered eating in females ${ }^{3}$, namely thin-Ideal internalization, social comparison, mood, personality traits (neuroticism), and body dissatisfaction. In fact, researchers have shown a direct association between disordered eating and body dissatisfaction ${ }^{4-6}$ (understood as the negative evaluation of one's own body) ${ }^{7-8}$ in adolescents. Body dissatisfaction is considered as one of the diagnostic criteria of anorexia nervosa ${ }^{9}$, but not necessarily of other eating disorders.

In addition to body dissatisfaction, certain personality traits may be associated with disordered eating ${ }^{10,11}$. Perfectionism, a multifaceted construct, 
is considered one of these traits ${ }^{11}$. High standards, accompanied by a tendency to criticize their own behavior are characteristics of individuals with this personality ${ }^{12}$ trait. In addition, scientific evidence indicates that perfectionists perceive imperfections of shape and body weight, which are currently intensified by continuous exposure to the media ideal body pattern ${ }^{13}$.

Disordered eating can also be influenced by mental condiditions ${ }^{11}$. Mood state can be understood as a set of positive and negative feelings persistent over a certain amount of time and that vary in intensity and duration ${ }^{14}$. Mood swings, especially caused by momentary selfdepreciation of the body, can lead to the development of eating disorders in search of the prefect body ${ }^{11}$. Thus, it is essential to understand how mood state can influence disordered eating.

Adolescence - period between 10 and 19 years of age ${ }^{15}$ - is a stage of many rapid and profound physical body changes, which have major importance for adolescents. Many studies on disordered eating in adolescents ${ }^{6,16}$ have been carried out, especially in females ${ }^{5,8}$. Researchers show that girls are more likely to develop eating disorders since the thin Ideal is the concept of the ideally slim female body for social acceptance ${ }^{13,17}$.

It is important to mention that studies on the association between perfectionism and mood state with disordered eating in female adolescents have not yet been shown in the scientific literature. In addition, adolescents who experience disordered eating often omit the problem ${ }^{1}$. The identification of certain features that indicate the profile of youngsters at risk of developing eating disorders can contribute to the use of prevention interventions that aim to prevent the onset of these disorders. Therefore, if there is any evidence associating perfectionism and mood state with disordered eating, it will be possible to identify young people at risk for the onset of eating disorders using psychometric instruments that assess perfectionism and/or mood. Thus, due to the scantiness of studies correlating these variables and the importance of this research from a practical point of view, the present study aimed to determine the association between body dissatisfaction, perfectionism, and mood with disordered eating in female adolescents in the city of Juiz de Fora (MG), Brazil.

\section{METHODS}

This study was approved by the Human Research Ethics Committee of School of Philosophy, Sciences and Letters of Ribeirão Preto - Universidade de São Paulo (Protocol $n^{\circ}$ 109.971) - according to the law $n^{\circ} 466 / 12$ issued by the National Health Council.

Initially, each school was contacted by the researchers and the objectives and procedures of the research project were explained. After their initial approval, the Free, Prior, and Informed Consent (FPIC) was given to the students who were informed about the procedures to be used when carrying out the research.

The data were collected once between March and September 2012. In the classroom, after having the FPIC signed by the participant schools, the students individually answered the questionnaires (Eating Attitudes Test - 26 [EAT-26], Body Shape Questionnaire [BSQ], Multidimensional Perfectionism Scale [MPS] and, Brunel Mood Scale [BRUMS]) and completed an identification field including age. These assessment instruments were carried out by the same researcher, who standardized the verbal communications. The study subjects did not communicate with each other, and here is no set time limit for answering the questionnaires.

The present study had a cross-sectional design. It was conducted with female adolescents, aged between 12 and 16, who live in the city of Juiz de Fora (MG). According to the 2011 School Census, the city had about 35,000 (thirty five thousand) young people in this age group enrolled in private and public schools. In order to calculate the sample size, prevalence of $30 \%$ of disordered eating $^{8}$, 5\% sampling error, 95\% confidence interval, and 1.4 in terms of design were used to 
determine a sample size of 318 adolescents. A total of 389 young people participated in the study, among which 18 were excluded because they did not respond to the questionnaire completely; therefore, there were 371 participants in the sample. The average age of the girls was 13.03 (Standard Deviation - SD=1.59).

The proportional sample was stratified according to each school socio-geographic regions (North, South, and Central part of the city) and their administrative operation status (public or private). According to the Board of Education of Juiz de Fora (MG), in 2012 there were 18 private and 23 public basic primary schools (children aged between 6 and 14 years) and secondary schools (children aged between 15 and 17 years) in the city about 1/3 of these schools was selected considering their administrative operation status (private or public). Accordingly, the principals of 6 private schools and 8 public schools were contacted; however, only 12 gave consent for the participation of their students in the research.

The participating schools were evenly distributed in the city of Juiz de Fora (MG): 6 schools ( 3 private and 3 public) in the central part, 2 schools (1 private and 1 public) in the southern part, and 4 schools ( 2 private and 2 public) in the northern part of the city. The institutions were selected based on the geographic location information provided by the government collecting organ of the Minas Gerais Department of Education.

The final sample was distributed among 12 different collection points ( 6 private and 6 public schools) and consisted of female adolescents present in the schools on the days of collection and whose parents gave permission for their participation in the research.

In order to participate in the study, the adolescent needed to be regularly enrolled in basic primary or secondary schools in the city of Juiz de Fora (MG), had to have availability to respond to the questionnaires, and provide the FPIC signed by their parents or guardians.

\section{Assessment instruments}

The Eating Attitudes Test - 26, validated for female adolescents ${ }^{18}$, was used to evaluate disordered eating. The questionnaire consisted of 26 questions divided into three factors: 1) Diet pathological refusal to eat high calorie foods and physical appearance issues; 2) Bulimia and Concern about Food: episodes of binge eating followed by compensatory behaviors such as purging for weight loss and weight control and; 3) Oral Self-Control: it indicates self-control in relation to food and assessment of environmental and social factors that can stimulate food intake. There were six response options on a Likert scale ranging from 0 (almost never and never) to 3 (always). The final score of this assessment instrument is obtained by the sum of its subscale scores, and the only question in the reverseworded questionnaire item was question number 25. In the sample of adolescents, scores equal to or greater than 21 represents individuals with disordered eating. However, the EAT-26 subscales were analyzed separately, according to the method used in another study ${ }^{4}$. It is noteworthy, however, that there is no specific cut-off point for the EAT-26 subscales although researchers suggest that scores above 20 for the subscale Diet and 10 for the other subscales may indicate subjects at risk of developing eating disorders ${ }^{4}$. In a study on validation of the EAT-26, Bighetti et al. ${ }^{18}$ found internal consistency of 0.82 . In the present study, the internal consistency (Cronbach's alpha) found in the sample evaluated was 0.87.

Dissatisfaction and concerns regarding body shape were evaluated using the BSQ, which was validated for female Brazilian adolescents ${ }^{19}$. This assessment instrument consists of a 34-item scale, and the responses are scored on a 6-point Likert scale ranging from 0 (almost never and never) to 3 (always). The overall score, the sum of direct item scores, may vary from 34 to 204. The authors who proposed this instrument established cut-off points so that the results are classified into four levels of body dissatisfaction: scores less than 80 - free from body dissatisfaction; 
between 80 and 110 - mild body dissatisfaction; between 110 and 140 - moderate dissatisfaction; and scores above 140 - marked or severe body dissatisfaction. Based on the statistical analysis, the adolescents identified as having some kind of dissatisfaction (mild, moderate, or severe) were considered as "dissatisfied". The internal consistency (Cronbach's alpha) found in the sample evaluated was 0.96 .

In order to measure the levels of perfectionism in the adolescents, the MPS was used; it was validated for the Portuguese language by Soares et al. ${ }^{12}$. The scale consists of 45 items that identify three dimensions of perfectionism: self-oriented perfectionism (involves self-directed cognitions and behaviors, harsh self-evaluation, and motivation in the pursuit of perfection and failure avoidance); socially prescribed perfectionism (involves the need to meet the standards and expectations created by significant others and the belief that people evaluate them stringently and exert pressure on them to be perfect); and otheroriented perfectionism (involves beliefs and expectations regarding the capabilities and performance of others). When answering the questions, the adolescent being evaluated should indicate her response on a Likert scale ranging from 1 (strongly disagree) to 7 (strongly agree). The overall score is calculated by the sum of the individual item scores; there were 19 reversed scored items. The overall score can vary from 45 to 315. The higher the score, the higher the perfectionism. Based on the data analysis, those with a score higher than 143 (median) were considered having high perfectionism (MPS+). The internal consistency (Cronbach's alpha) found in the sample evaluated was 0.93 .

Mood state was measured using the BRUMS scale, validated by Rohlfs et al. ${ }^{20}$. This scale is divided into 6 subscales: Anger (unstable emotional state from mild irritation to rage associated with the autonomic nervous system stimulation); Mental Confusion (feelings of uncertainty and instability affecting control emotions and attention); Depression (feelings of self-depreciation, emotional isolation, sadness, difficulty of adaptation, and low self-esteem or negative self-image), Fatigue (exhaustion, apathy, and low level of energy), Tension (high musculoskeletal tension, agitation, and restlessness) and Vigor (feelings of excitement, disposition, and physical energy). Each subscale contains 4 items; the adolescents evaluated were asked to state their feelings over the past few days, including the day of the test, using a Likert scale ranging from 0 (not) to 4 (extremely). The overall score is calculated by the sum of the individual item scores and can range from 0 to 96. The subscales Tension, Depression, Anger, Fatigue, and Mental Confusion are considered negative mood factors, and Vigor considered a positive factor. The Total Mood Disturbance (TMD) was obtained by adding the negative factors and the core of the positive mood factor. Based on the statistical analysis, BRUMS scale median (28) was used to classify the adolescents with high ( $\geq 28)$ and low (<28) TMD. The internal consistency (Cronbach's alpha) found in the sample evaluated was 0.88 .

The anthropometric information was collected by the same experienced evaluator. Body mass was measured using a portable digital scale (Tanita - $100 \mathrm{~g}$ precision and maximum capacity of $200 \mathrm{~kg}$ ). A portable stadiometer, $0.1 \mathrm{~cm}$ accuracy and $2.20 \mathrm{~m}$ maximum height (Welmy), was used to measure the height of adolescents. The Body Mass Index (BMI) was obtained according to the common calculation: $\mathrm{BMI}=$ body weight $(\mathrm{kg}) /$ height $\left(\mathrm{m}^{2}\right)$. Since some scientific reports have indicated association between BMI and disordered eating in adolescents ${ }^{4,6}$, the BMI was monitored during the statistical analyses.

The school administrative operation status (public or private) was used as the variable "type of school", and it was an indirect indicator of students' socioeconomic status, according to the method used in another study? ${ }^{7}$. Since scientific evidences indicate an association between socioeconomic status and disordered eating ${ }^{2,6}$, 
the administrative status of the schools was monitored during some statistical analyses.

The Kolmogorov-Smirnov normality test was performed and it did not indicate skewed distribution. Therefore, measures of central tendency (mean and median), dispersion (standard deviation, maximum, and minimum values), and frequency (absolute and relative) were used to describe the variables being investigated. Four stepwise multiple linear regressions were carried out in three blocks monitoring age, BMI, and type of school (private and public) to investigate the association between the independent variables (BSQ, MPS, and BRUMS) and the EAT-26 scores and its subscales (Diet, Bulimia and Concern about Food, and Oral Self-control). A binary logistic regression was used to investigate the association between the disordered eating classifications (EAT-26 $\geq 21$ ) and body dissatisfaction (BSQ $<80=$ satisfied and BSQ $\geq 80=$ dissatisfied), perfectionism (MPS $<143=$ low perfectionism; MPS $\geq 143=$ high perfectionism), and mood state (BRUMS $<28=$ low TMD and BRUMS $\geq 28=$ high TMD), monitoring age, BMI, and type of school (private and public). In addition, the Multivariate Analysis of Covariance (Mancova) was used to compare the EAT-26 subscale scores based on the body dissatisfaction scores (BSQ $<80=$ satisfied and BSQ $\geq 80=$ dissatisfied), perfectionism (MPS <143=low perfectionism; MPS $\geq 143=$ high perfectionism), and mood (BRUMS <28=low TMD and BRUMS $\geq 28=$ high TMD), including age, BMI, and type of school (private and public) as covariates. The data were analyzed using the Statistical Package for the Social Sciences (SPSS Inc., Chicago, United States) 21.0 software adopting a significance level of $5 \%$.

\section{RE S U L T S}

The means and standard deviations of the EAT-26 subscales were: $8.79 \pm 2.36$ (subscale Diet), $2.28 \pm 1.29$ (subscale Bulimia and Concern about Food) and 3.40 \pm 1.87 (subscale Oral Self-control).

The Eating Attitudes Test - 26 results indicated prevalence of $21.7 \%$ of disordered eating. As for the BSQ, the results found indicated that $23.2 \%$ of the adolescent girls had body dissatisfaction, distributed as follows: mild dissatisfaction, 14.5\%; moderate dissatisfaction, $5.8 \%$; and severe dissatisfaction, $2.9 \%$. With regard to MPS, $46.4 \%$ of the evaluated adolescents had high perfectionism. In addition, the findings revealed that $47.8 \%$ of adolescents had high TMD (Table 1).

The descriptive values (minimum, maximum, mean and standard deviation) of all variables are shown in Table 1.

Table 1. Descriptive values of the variables studied.

\begin{tabular}{lcccc}
\hline Variable & Minimum & Maximum & Mean & SD \\
\hline EAT-26 & 0.00 & 54.00 & 13.33 & 11.68 \\
BSQ & 34.00 & 186.00 & 65.26 & 33.36 \\
MPS & 45.00 & 205.00 & 124.99 & 59.23 \\
BRUMS & 0.00 & 64.00 & 20.80 & 14.76 \\
BMl $\left(\mathrm{kg} / \mathrm{m}^{2}\right)$ & 13.22 & 34.81 & 21.16 & 3.70 \\
Age (years) & 12.00 & 16.00 & 13.03 & 1.59 \\
& & $\%$ & & \\
Disorded eating & & 21.7 & & \\
Body insatisfaction & & 23.2 & & \\
High perfectionism & 46.4 & & \\
High TMD & 47.8 & & \\
\hline
\end{tabular}

Note: SD: Standard Deviation; EAT-26: Eating Attitudes Test; BSQ: Body Shape Questionnaire; MPS: Multidimensional Perfectionism Scale; BRUMS: Brunel Mood Scale; BMI: Body Mass Index; TMD: Total Mood Disturbance. 
The results showed that body dissatisfaction explained $51 \%$ of the variance of disordered eating $\left(\mathrm{F}_{(1,370)}=97.65 ; \mathrm{B}=0.24 ; R^{2}=0.51 ; p=0.001\right)$. However, the MPS included in the block 2 of the regression model indicated no association with disordered eating $\left(\mathrm{F}_{(2,369)}=7.51, \mathrm{~B}=0.09, R^{2}=0.07\right.$, $p=0.31$ ). In the last block of the regression model, TMD increased the magnitude of the association with disordered eating, explaining $7 \%$ of its variance $\left(\mathrm{F}_{(3,368)}=11.62, \mathrm{~B}=0.13, R^{2}=0.14 ; p=0.01\right)$.

The logistic regression model showed an association between disordered eating (EAT-26 $\geq 21)$ and body dissatisfaction $\left(\chi^{2}=26.79\right.$; Wald $=22.07 ; O R=4.62 ; p=0.01)$. Thus, the adolescents dissatisfied with their own bodies (BSQ $\geq 80$ ) showed 4.62 times more likely to develop eating disorders than those who were satisfied with their bodies (BSQ <80). The logistic regression results indicated no association between perfectionism and disordered eating $\left(\chi^{2}=4.50 ;\right.$ Wald $\left.=2.32 ; O R=0.87 ; p=0.17\right)$. On the other hand, a statistically significant association between mood and disordered eating $\left(\chi^{2}=16.01\right.$; Wald=13.34; $O R=2.11 ; p=0.02$ ) Was found. Accordingly, the adolescents with high TMD (BRUMS $\geq 28$ ) were 2.11 times more likely to develop eating disorders than those with low TMD (BRUMS <28).

The regression model shown in Table 2 indicates only the association between the BSQ $\left(F_{(1,370)}=119.05, p=0.001\right)$ and the EAT-26 subscale Diet. Thus, this result indicates that body dissatisfaction explained $64 \%$ of the variance in dietary restriction in female adolescent. However, MPS $\left(F_{(2,369)}=0.55, p=0.60\right)$ and BRUMS $\left(F_{(3,368)}=0.39, p=0.72\right)$ did not show statistically significant association with the subscale Diet. Therefore, these findings showed that perfectionism and mood were not associated with dietary restriction of the students of the schools in Juiz de Fora (MG). Nevertheless, when all the variables were included in a single block, $66 \%$ of dietary restriction variance was explained $\left(F_{(1,370)}=42.03\right.$, $p=0.001)$. It is worth noting that age $\left(F_{(1,370)}=5.68\right.$, $p=0.04), \mathrm{BMI}\left(\mathrm{F}_{(1,370)}=29.39, p=0.01\right)$, and type school $\left(F_{(1,370)}=7.51, p=0.04\right)$ showed covariance with the scores of the subscale Diet. These findings indicate that the higher the age, the higher the frequency of dietary restrictions or the higher the $\mathrm{BMI}$, the higher the frequency of dietary restriction. As for the type of school, the results indicated that dietary restriction was more

Table 2. Multiple linear regression using the BSQ, MPS, and BRUMS as variables to explain the variance of the Eating Attitudes Test - 26 subscale Diet in female adolescents.

\begin{tabular}{lcccccc}
\hline Variable & Block & $B$ & $R$ & $R^{2}$ & $R^{2^{*}}$ & $p$-value \\
\hline BSQ & 1 & 0.17 & 0.80 & 0.64 & 0.64 & 0.001 \\
MPS & 2 & 0.008 & 0.07 & 0.004 & 0.003 & 0.60 \\
BRUMS & 3 & 0.02 & 0.04 & 0.002 & 0.001 & 0.72 \\
All & & 2.29 & 0.82 & 0.68 & 0.66 & 0.01 \\
\hline
\end{tabular}

Note: $R^{2^{*}}$ : Adjusted $R^{2}$; BSQ: Body Shape Questionnaire; MPS: Multidimensional Perfectionism Scale; BRUMS: Brunel Mood Scale.

Table 3. Multiple linear regression using the BSQ, MPS, and BRUMS as variables to explain the variance of the Eating Attitudes Test - 26 subscale Bulimia and Concern about Food in female adolescents.

\begin{tabular}{lcccccc}
\hline Variable & Block & $B$ & $R$ & $R^{2}$ & $R^{2^{*}}$ & $p$-value \\
\hline BSQ & 1 & 0.12 & 0.64 & 0.41 & 0.40 & 0.01 \\
MPS & 2 & 0.10 & 0.26 & 0.07 & 0.06 & 0.04 \\
BRUMS & 3 & 0.10 & 0.28 & 0.08 & 0.06 & 0.02 \\
All & & 2.72 & 0.67 & 0.46 & 0.43 & 0.01 \\
\hline
\end{tabular}

Note: $R^{2 *}$ : Adjusted $R^{2}$; BSQ: Body Shape Questionnaire; MPS: Multidimensional Perfectionism Scale; BRUMS: Brunel Mood Scale. 
closely associated to private school adolescents than public school adolescents.

Table 3 shows the regression model, in which the subscale Bulimia and Concern about Food was used as the criterion variable. The results showed statistically significant association between BSQ $\left(F_{(1,370)}=45.98, p=0.001\right)$, MPS $\left(F_{(2,369)}=5.32, p=0.031\right)$, and BRUMS $\left(F_{(3,368)}=5.07\right.$, $p=0.02$ ). Therefore, these findings showed that body dissatisfaction (41\%), perfectionism (7\%), and mood (8\%) were associated to binge eating and purging behaviors in the female adolescents evaluated. It is also worth mentioning that all independent variables together (BSQ, MPS, and BRUMS) explained 43\% ( $\left.F_{(1,370)}=29.02, p=0.001\right)$ of the variance in the EAT-26 subscale Bulimia and Concern about Food. It should be noted that $\mathrm{BMI}\left(\mathrm{F}_{(1,370)}=23.04, p=0.01\right)$ showed covariance with the subscale Bulimia and Concern about Food scores; the same behavior was not observed for age $\left(F_{(1,370)}=1.18 ; p=0.28\right)$ and type of school $\left(F_{(1,370)}=1.76, p=0.19\right)$. These results demonstrate that the higher the BMI, the higher the bulimic symptom frequency; nevertheless, there were no associations between age and type of school (private or public) with symptoms of bulimia.

Table 4 shows the last regression model, in which the subscale oral self-control was used as the dependent variable. BSQ $\left(F_{(1,370)}=7.57\right.$, $p=0.007)$ and $\operatorname{BRUMS}\left(F_{(3,368)}=2.33, p=0.05\right)$ showed significant association with the scores of the subscale oral self-control. Accordingly, MPS $\left(F_{(2,369)}=0.69, p=0.48\right)$ did not explain the variance of the self-control towards food in the female adolescents. However, it is important to mention that the regression model with all explanatory variables (BSQ, MPS, and BRUMS) included in a single block $\left(F_{(1,370)}=9.25 ; p=0.026\right)$ explained $10 \%$ of the variance of the EAT-26 subscale oral self-control. It was also observed that BMI $\left(F_{(1,370)}=17.33, p=0.02\right)$ and type of school $\left(F_{(1,370)}=6.61, p=0.03\right)$ showed covariance with the scores of subscale oral self-control, which was not observed for age $\left(F_{(1,370)}=1.55, p=0.25\right)$. These findings indicate that the higher the BMI, the greater the perception of environmental factors that influence food intake. In addition, the adolescents of private schools were associated with the perceptions of these environmental factors to a greater extent than the public school students. Finally, the results indicated no direct association between age and perception of environmental factors that can influence food intake.

With regard to comparisons of the EAT-26 subscales based on the body dissatisfaction groups, the Mancova analysis revealed significant results (Table 5): 1) it showed score differences in the subscales Diet $\left(F_{(6,365)}=157.02 ; p=0.001\right)$ and Bulimia and Concern about Food $\left(F_{(6,365)}=63.70\right.$; $p=0.001$ ) between the adolescents satisfied and dissatisfied with their bodies and; 2) there were similarities in the scores of the subscale oral selfcontrol between the adolescents satisfied and dissatisfied with their bodies $\left(F_{(6,365)}=1.38\right.$; $p=0.24)$. As for perfectionism, the results of the Mancova analysis indicated differences in the frequency of bulimic behavior $\left(F_{(6,365)}=7.84\right.$; $p=0.033)$, and environmental influences on food intake $\left(F_{(6,365)}=6.01 ; p=0.048\right)$ in adolescents with high and low perfectionism traits (Table 5).

Table 4. Multiple linear regression using the BSQ, MPS, and BRUMS as variables to explain the variance of the Eating Attitudes Test - 26 subscale oral self-control in female adolescents.

\begin{tabular}{lcccccc}
\hline Variable & Block & $B$ & $R$ & $R^{2}$ & $R^{2^{*}}$ & $p$-value \\
\hline BSQ & 1 & 0.10 & 0.32 & 0.10 & 0.09 & 0.01 \\
MPS & 2 & 0.006 & 0.09 & 0.008 & 0.007 & 0.48 \\
BRUMS & 3 & 0.06 & 0.20 & 0.04 & 0.03 & 0.05 \\
All & & 6.56 & 0.37 & 0.14 & 0.10 & 0.03 \\
\hline
\end{tabular}

Note: $R^{2^{*}}$ : Adjusted $R^{2}$; BSQ: Body Shape Questionnaire; MPS: Multidimensional Perfectionism Scale; BRUMS: Brunel Mood Scale. 
Table 5. Comparison of the Eating Attitudes Test - 26 subscale scores regarding the groups of female adolescents with body dissatisfaction, perfectionism, and mood state.

\begin{tabular}{|c|c|c|c|}
\hline \multirow{2}{*}{$\frac{\text { Variable }}{\text { Dissatisfied }}$} & \multicolumn{2}{|c|}{ Group } & \multirow[t]{2}{*}{$p$-value } \\
\hline & Satisfied (BSQ <80) & Dissatisfied (BSQ $\geq 80$ ) & \\
\hline \multicolumn{4}{|c|}{ Mean (SD) } \\
\hline Diet & $5.49( \pm 0.85)$ & $15.95( \pm 1.51)$ & 0.01 \\
\hline BUL and CAF & $0.94( \pm 0.30)$ & $4.48( \pm 0.54)$ & 0.01 \\
\hline Oral SC & $3.20( \pm 0.52)$ & $4.55( \pm 0.99)$ & 0.24 \\
\hline Perfectionism & Low (MPS < 143) & High (MPS $\geq 143$ ) & \\
\hline \multicolumn{4}{|c|}{ Mean (SD) } \\
\hline Diet & $8.06( \pm 1.29)$ & $7.87( \pm 1.36)$ & 0.72 \\
\hline BUL and CAF & $1.17( \pm 0.40)$ & $2.35( \pm 0.45)$ & 0.04 \\
\hline Oral SC & $2.81( \pm 0.65)$ & $4.33( \pm 0.66)$ & 0.05 \\
\hline TMD & Low (BRUMS <28) & High (BRUMS $\geq 28$ ) & \\
\hline \multicolumn{4}{|c|}{ Mean (SD) } \\
\hline Diet & $7.95( \pm 1.29)$ & $8.02( \pm 1.31)$ & 0.84 \\
\hline BUL and CAF & $1.21( \pm 0.40)$ & $2.41( \pm 0.44)$ & 0.05 \\
\hline Oral SC & $2.99( \pm 0.63)$ & $4.02( \pm 0.65)$ & 0.26 \\
\hline
\end{tabular}

Note: BUL and CAF: Bulimia and Concern about Food; SD: Standard Deviation; BSQ: Body Shape Questionnaire; MPS: Multidimensional Perfectionism Scale; BRUMS: Brunel Mood Scale; TMD: Total Mood Disturbance.

However, similar scores were observed in the subscale Diet $\left(F_{(6,365)}=0.91 ; p=0.72\right)$ for the adolescents with low and high perfectionism traits. Finally, with regard to mood, the Mancova analysis results showed differences only in the subscale Bulimia and Concern about Food $\left(F_{(6,365)}=6.05 ; p=0.049\right)$. In contrast, similarities were found between dietary restriction $\left(F_{(6,365)}=0.35\right.$; $p=0.84)$ and oral self-control $\left(F_{(6,365)}=1.14 ; p=0.26\right)$ between the adolescents with high and low TMD, as shown in Table 5.

\section{DISCUSSION}

The objective of the present study was to investigate the association between body dissatisfaction, perfectionism, and mood with disordered eating in female adolescents. The analysis of factors associated with disordered eating in adolescents is of great importance since the results can help preventing the onset of eating disorders.

Considering the total score of the EAT-26, the results indicated an association between body dissatisfaction and disordered eating in both regression models used (multiple and logistic regression), corroborating the findings of other studies $^{4-6}$. In fact, adolescents dissatisfied with their bodies are more closely associated with the development of eating disorders ${ }^{8,13}$. In contrast, there was no association between perfectionism and disordered eating, which contradicts the findings of other researchers ${ }^{11}$. According to Neves et al. ${ }^{21}$, perfectionism is included in the causes of eating disorders in young women. With regard to mood, the results obtained in the present study showed an association with disordered eating in both multiple as logistic regressions. It seems that the adolescents with negative mood can develop eating disorders as an alternative to mitigate the magnitude of its feelings (depression, tension, and anger) ${ }^{21}$.

The results of this study showed an association between body dissatisfaction and behavior towards dietary restriction (in both the regression model and in the multivariate analysis of covariance). In fact, other authors have also found that dissatisfaction with body weight, shape, and physical appearance trigger the 
practice of dietary restriction by female adolescents as an approach for weight loss ${ }^{4,13}$. Rodgers et al. ${ }^{17}$ found that female adolescents dissatisfied with their bodies can go for long periods without eating any type of food as an alternative to losing weight and body fat. Nevertheless, it is important to mention that binge eating is common after a fast, among female adolescents ${ }^{1,9}$, which is also considered harmful to health ${ }^{13}$.

Similarly, the results obtained showed association between body dissatisfaction and episodes of binge eating and compensatory behaviors (multiple regression model and multivariate analysis of covariance). This result is in agreement with the tripartite influence model of body image ${ }^{17}$, which indicates a direct association between body dissatisfaction and symptoms of bulimia. Corroborating evidences suggest that binge eating and the use of laxatives and diuretics result from dissatisfaction with body shape and weight ${ }^{13,16}$. Therefore, uncomfortable feelings with one's body after episodes of binge eating can trigger purging behaviors ${ }^{9}$. In other words, adolescents who feel self-conscious and awkward about their physical appearance can use laxatives/diuretics or appetite suppressants regularly and/or engage in strenuous physical activity as measures to maintain or reduce body weight ${ }^{13,16}$. Nevertheless, the possibility of a vicious cycle should be considered, i.e., female adolescents dissatisfied with their bodies may fast (dietary restriction), but it is known that food abstinence can lead to binge eating followed by compensatory behaviors (purging) in order to maintain or reduce body weight ${ }^{1}$, characterizing a cycle that can, in the long run, lead to health problems ${ }^{4}$.

With regards to oral self-control, the findings of this study showed an association between it and body dissatisfaction only according to the regression model. In fact, body dissatisfaction has been identified as a factor that stimulates the perception of environmental factors that can influence food intake (assessed by the
EAT-26 subscale oral self-control $)^{9,17}$. Therefore, high body concerned female adolescents may feel pressured to adopt alternative methods of weight control $^{12}$.

Nevertheless, the results obtained did not suggest an association between perfectionism and dietary restriction. Although perfectionism is considered as a personality trait present in patients diagnosed with eating disorders ${ }^{12}$, there is still no consensus in the literature regarding the association between perfectionism and disordered eating. It is worth noting that female adolescents who have perfectionist traits tend to worry about social acceptance $^{11}$. Considering that social acceptance among adolescents may be associated with physical appearance ${ }^{17}$, female adolescents can adopt dietary restriction for long periods of time to reduce body weight, which was not evidenced in the present study. Therefore, further research is needed to identify the possible association between perfectionism and dietary restriction.

On the other hand, the association between perfectionism and binge eating and purging behaviors was identified. It seems that young women with perfectionist traits can selfinduce vomiting or misuse laxatives and diuretics in order to lose weight ${ }^{9}$. Accordingly, adolescents that show perfectionist traits may develop purging behaviors in search of social acceptance ${ }^{16}$. It should be noted, however, that the findings of this study indicated that only $7 \%$ of compulsive overeating and purging behaviors were explained by perfectionism, which suggests that other personal characteristics may be associated to these behaviors. Therefore, these results should be interpreted with some caution.

Multivariate analysis of covariance was the only one to show an association between perfectionism and oral self-control. Adolescents with high perfectionism showed more self-control over food intake. Several studies have indicated that those with extreme perfectionism often feel more pressure to adopt dietary patterns similar to those of people who they consider important, 
such as parents, friends and idols ${ }^{10-11}$, which, to a certain extent, explains these findings.

With regard to mood state, there was no association with food restriction in female adolescents, corroborating the findings of Neves et al. ${ }^{21}$. However, it was found in the present study that feelings such as anger, tension, and depression were associated with restrictive eating behaviors ${ }^{11}$. It is worth mentioning that the aforementioned studies were conducted with athletes. Therefore, further research is needed to determine the influence of mood on the dietary restriction in young women.

On the other hand, it was shown that mood was associated to binge eating and purging behaviors. Researchers argue that adolescents with negative mood state (depression, anger, and tension) can develop episodes of binge eating, especially carbohydrates, because these foods induce neurotransmitter secretions associated with feelings of happiness, for example serotonina ${ }^{22}$. In addition, there is scientific evidence that high carbohydrate foods can lead to an increase in the synaptic transmission of monoamines, considered one of the mechanisms to reduce the magnitude negative mood states ${ }^{23}$. Thus, adolescents experiencing negative mood state may eat excessive amounts of high carbohydrate foods in order to reduce feelings such as anger, depression, and tension.

Finally, it was shown that the multiple regression model was the only one that indicated an association between mood and Oral Self-Control. Although there is no evidence that mood influences the perception of environmental factors that can influence food intake (EAT-26 oral self-control subscale), it is believed that female adolescents wit high TMD may be more influenced by parents and friends to adopt specific eating habits aiming to lose weight.

The limitations of the present study should be highlighted. The major limitation was the use of self-reported assessment instruments. Some researchers argue that the individuals been evaluated may not respond to the questionnaires honestly since the responses are subjective and thus easy to cheat ${ }^{13,17,24-25}$. However, Miranda et al. ${ }^{7}$ highlighted that in population-based studies or those with large samples, anamnesis (interviews information gained by a physician by asking specific questions) conducted with easily applicable tools, such as questionnaires, may be the most appropriate method to be used. Another limitation was the cross-sectional design; causal inference is usually not possible from a cross-sectional study. Therefore, it was not possible to assess the kind and intensity of the relationships between this study results and the independent variables. However, since this study is the first one to evaluate the association between some factors and disordered eating in Brazilian adolescents, it is believed that the results obtained can contribute to bridge the knowledge gap of this field of study, and therefore they deserve some more attention in future studies.

\section{CONCLUSION}

In summary, only body dissatisfaction was found to be associated with dietary restriction, symptoms of bulimia, and oral self-control. Mood state was associated with symptoms of bulimia and oral self-control, whereas perfectionism was associated only with the symptoms of bulimia.

From a practical point of view, school staff should be aware of adolescents dissatisfied with their bodies, perfectionists, and those with negative mood state (Anger, Hostility, Tension, and Depression). The presence of psychologists and nutritionists in schools is of great importance in order to implement prevention programs focusing on reducing body dissatisfaction, perfectionism, and negative mood state thus reducing the risk of triggering eating disorders in adolescents.

Finally, it is suggested that further studies are carried out to investigate possible effects and influences of socio-cultural agents such as media and friends on disordered eating in adolescents, besides longitudinal studies to evaluate the causal relationships between these variables. 


\section{CONTRIBUTORS}

LS FORTES prepared the research project, collected data and wrote article. JF FILGUEIRAS and CM NEVES assisted in data collection, data analysis and revising article. SS ALMEIDA conducted statistical analysis and revised article. MEC FERREIRA guided all work and revised article.

\section{RE FERE N CES}

1. Leal GVS, Philippi ST, Polacow VO, Cordás TA, Alvarenga MS. O que é comportamento de risco para transtornos alimentares em adolescentes? J Bras Psiquiatr. 2013; 62(1):62-75. http://dx.doi.org/ 10.1590/S0047-20852013000100009

2. Ferreira JES, Vieira GV. Eating disorder risk behavior in Brazilian adolescents from low socio-economic level. Appetite. 2008; 51(2):249-55. http://dx.doi. org/10.1016/j.appet.2008.02.015

3. Huxley CJ, Halliwell E, Clarke V. An examination of the tripartite influence model of body image: Does women's sexual identity make a difference? Psychol Women Quart. 2014; 20:1-12. http://dx.doi.org/ 10.1177/0361684314554917

4. Fortes LS, Amaral ACS, Almeida SS, Ferreira MEC. Efeitos de variáveis psicológicas, morfológicas e sociodemográficas sobre o comportamento alimentar de adolescentes. Rev Paul Ped. 2013; 31(2):182-8. http://dx.doi.org/10.1590/S0103-0582201300 0200008

5. Alves E, Vasconcelos FAG, Calvo MCM, Neves J. Prevalence of symptoms of anorexia nervosa and dissatisfaction with body image in female adolescents in Florianópolis, Santa Catarina, Brazil. Cad Saúde Pública. 2008; 24(3):503-12. http:// dx.doi.org/10.1590/S0102-311X2008000300004

6. Fortes LS, Morgado FFR, Ferreira MEC. Fatores associados ao comportamento alimentar inadequado em adolescentes escolares. Rev Psiquiatr Clín. 2013; 40(2):59-64. http://dx.doi.org/10.1590/S0101-60 832013000200002

7. Miranda VPN, Conti MA, Bastos R, Ferreira MEC. Body dissatisfaction in Brazilian adolescents in small towns of Minas Gerais. J Bras Psiquiatr. 2011; 60(3):190-7. http://dx.doi.org/10.1590/S0047-20 852011000300007

8. Scherer FC, Martins CR, Pelegrini A, Matheus SC, Petroski EL. Imagem corporal em adolescentes: associação com a maturação sexual e sintomas de transtornos alimentares. J Bras Psiquiatr. 2010; 59(3):198-202. http://dx.doi.org/10.1590/S0047-20 852010000300005
9. Saikali CJ, Soubhia CS, Scalfaro BM, Cordás TA. Imagem corporal nos transtornos alimentares. Rev Psiquiatr Clín. 2004; 31(4):164-6. http://dx.doi.org/ 10.1590/S0101-60832004000400006

10. Filaire E, Rouveix M, Pannafieux C, Ferrand C. Eating atitudes, perfectionism and body-esteem of elite male judoists and cyclists. J Sports Sci Med. 2007; 6(1):50-7.

11. Rouveix M, Bouget M, Pannafieux C, Champely S, Filaire E. Eating attitudes, body esteem, perfectionism and anxiety of judo athletes and nonathletes. Int J Sports Med. 2007; 28(2):340-5.

12. Soares MJ, Gomes AA, Macedo AF, Azevedo MHP. Escala Multidimensional de Perfeccionismo: adaptação portuguesa. Rev Port Psicossomática. 2003; 5(1):46-55.

13. Flament MF, Hill EM, Buckholz A, Henderson K, Tasca GA. Internalization of the thin and muscular body ideal and disordered eating in adolescence: The mediation effects of body esteem. Body Image. 2012; 9(1):68-75. http://dx.doi.org/10.1016/ j.bodyim.2011.07.007

14. Werneck FZ, Navarro CA. Physical activity level and state of mood in adolescents. Psicol Teor Pesquisa. 2011; 27(2):189-93. http://dx.doi.org/10.1590/s0 102-37722011000200010

15. World Health Organization. Development of a WHO growth reference for school-aged children and adolescents. Bull World Health Organ. 2007; 85(9):660-7. http://dx.doi.org/10.1590/S0042-968 62007000900010

16. Caqueo-Urizar A, Ferrer-Garcia M, Toro J, GutierrezMaldonado J, Penaloza C, Cuadros-Sosa Y, et al. Associations between sociocultural pressures to be thin, body distress, and eating disorder symptomatology among Chilean adolescent girls. Body Image. 2011; 8(1):78-81. http://dx.doi.org/10.10 16/j.bodyim.2010.11.004

17. Rodgers R, Cabrol H, Paxton SJ. An exploration of the tripartite influence model of body dissatisfaction and disordered eating among Australian and French college women. Body Image. 2011; 8(1):208-15. http://dx.doi.org/10.1016/j.bodyim.2011.04.009

18. Bighetti F, Santos CB, Santos JE, Ribeiro RPP. Tradução e avaliação do Eating Attitudes Test em adolescentes do sexo feminino de Ribeirão Preto, São Paulo. J Bras Psiquiatr. 2004; 53(6):339-46.

19. Conti MA, Cordás TA, Latorre MRDO. Estudo de validade e confiabilidade da versão brasileira do Body Shape Questionnaire (BSQ) para adolescentes. Rev Bras Saúde Mater Infant. 2009; 9(3):331-8. http://dx.doi.org/10.1590/S1519-38292009000 300012

20. Rohlfs ICPM, Rotta TM, Luft CDB, Andrade A, Krebs RJ, Carvalho T. A Escala de Humor de Brunel (BRUMS): 
instrumento para detecção precoce da síndrome do excesso de treinamento. Rev Bras Med Esporte. 2008; 14(3):176-81. http://dx.doi.org/10.1590/S15 17-86922008000300003

21. Neves CM, Filgueiras JF, Fortes LS, Ferreira MEC. Comportamentos alimentares em ginastas: associação com o perfeccionismo e o estado de humor. Rev Educ Fís. 2013; 24(3):359-69. http://dx. doi.org/10.4025/reveducfis.v24.3.20850

22. Fortes LS, Almeida SS, Ferreira MEC. Processo maturacional, insatisfação corporal e comportamento alimentar inadequado em jovens atletas. Rev Nutr. 2012, 5(5):575-86. http://dx.doi.org/10.1590/S14 15-52732012000500003

23. Peluso MAM, Andrade LHSG. Physical activity and mental health: The association between exercise and mood. Clinics. 2005; 61(1):61-70. http://dx. doi.org/10.1590/S1807-59322005000100012

24. Ferrari EP, Petroski EL, Silva DAS. Prevalence of body image dissatisfaction and associated factors among physical education students. Trends Psychiatry Psychother. 2013; 35(2):119-27. http://dx.doi.org/ 10.1590/S2237-60892013000200005

25. Fortes LS, Morgado FFR, Almeida SS, Ferreira MEC. Eating behavior and physical activity in adolescents. Rev Nutr. 2013; 26(5):529-37. http://dx.doi.org/10. 1590/S1415-52732013000500004

Received: September 10, 2014 Final version: February 20, 2015 Approved: March 5, 2015 
